\title{
PENGARUH PENGGUNAAN BATA MERAH DAN BATA RINGAN TERHADAP DIMENSI PONDASI DAN HARGA RUMAH TIPE 54
}

\author{
Aunur Rafik ${ }^{(1)}$, Muhammad Humaidi ${ }^{(1)}$, Rinova Firman Cahyani ${ }^{(1)}$, \\ (1)rafik@poliban.ac.id, ${ }^{(2)}$ humai_d@poliban.ac.id, ${ }^{(3)}$ rinovafc@poliban.ac.id \\ (1) Staf Pengajar Jurusan Teknik Sipil, Politeknik Negeri Banjarmasin
}

\begin{abstract}
Ringkasan
Keamanan dan kenyamanan merupakan hal yang perlu mendapat perhatian serius dalam membangun sebuah rumah. Sering terjadi kasus ambruknya rumah yang diakibatkan karena tidak kuatnya struktur rumah. Pemilihan material penyusun dinding menjadi penting diperhatikan karena penurunan struktur pondasi juga diakibatkan beratnya beban dinding. Terutama bangunan rumah pada daerah rawa atau tanah lunak. Bata ringan menjadi bahan baku alternatif dalam pekerjaan pasangan dinding. Perbedaan bentuk, ukuran dan berat pada bata merah dan bata ringan mempengaruhi beban yang ditanggung oleh elemen struktur bangunan seperti balok, kolom dan pondasi. Penelitian ini menganalisis pengaruh material dinding berupa bata merah dan bata ringan terhadap dimensi struktur bawah/pondasi dan harga untuk rumah tipe 54.

Penelitian ini menggunakan metode deskriptif dan komparatif. Metode deskriptif digunakan untuk mendeskripsikan bagaimana pengaruh material bata merah dan bata ringan terhadap dimensi struktur pondasi. Sedangkan metode komparatif digunakan untuk membandingkan hasil perhitungan harga rumah tipe 54 antara material dinding berupa bata merah dan bata ringan.

Berdasarkan analisis dan perhitungan, pondasi rumah yang pasangan dindingnya menggunakan material bata ringan dimensinya lebih kecil dan harga rumahnya lebih murah dibanding menggunakan material bata merah. Pada penggunaan bata merah harga bangunan rumah Rp 350.964.275. Sedangkan pada penggunaan bata ringan harga bangunan rumah Rp 304.350.739. Kesimpulannya penggunaan material bata ringan menjadikan harga bangunan rumah lebih murah $\mathrm{Rp} 46.613,536$ (13,28 \%) dibanding menggunakan material bata merah
\end{abstract}

Kata kunci: bata merah, bata ringan, harga rumah.

\section{A. PENDAHULUAN}

Rumah merupakan bangunan tempat tinggal manusia yang digunakan untuk berteduh dan melakukan aktifitas kehidupannya. Keamanan dan kenyamanan saat berada di dalam rumah merupakan hal yang sangat penting. Terutama bangunan rumah pada daerah rawa dan tanah lunak. Sering terjadi kasus ambruknya rumah yang diakibatkan karena tidak kuatnya struktur rumah.

Untuk rumah tembok yang harus diperhatikan adalah bagian pondasi, sloof, kolom, balok dan rangka atap. Semua komponen tersebut perlu dihitung dan direncanakan sedemikian rupa sehingga didapatkan jenis, jumlah dan dimensi material bangunan yang kuat untuk digunakan. Pemilihan material penyusun dindingpun menjadi hal yang perlu diperhatikan karena seringkali hal yang menyebabkan struktur pondasi mengalami penurunan yaitu beratnya beban dinding. Umumnya material penyusun dinding yang digunakan adalah bata merah. Bata ringan hadir sebagai salah satu terobosan baru dengan dimensi yang lebih besar serta kualitas yang lebih seragam daripada bata merah. Bata ringan materialnya menyerupai beton dan memiliki sifat kuat, tahan air dan api serta awet. Bata ringan Citicon dapat diaplikasikan pada bangunan karena dapat memperkecil biaya struktur bangunan disebabkan sifat bata ringan Citicon memperkecil beban dinding pada struktur bangunan.( Putra, H.P. : 2010)

Perbedaan bentuk, ukuran dan berat dari bata merah dan bata ringan mempengaruhi beban yang ditanggung oleh elemen struktur bangunan seperti balok, kolom dan pondasi. Penelitian ini menganalisis pengaruh penggunaan material penyusun dinding berupa bata merah dan bata ringan terhadap dimensi pondasi dan pengaruhnya terhadap harga rumah tipe 54 .

\section{B. LANDASAN TEORI}

\section{Bata Merah}

Bata merah merupakan suatu unsur bangunan yang diperuntukkan pembuatan 
konstruksi bangunan dan yang dibuat dari tanah liat dengan atau tanpa campuran bahan-bahan lain, dibakar cukup tinggi, hingga tidak dapat hancur lagi bila direndam dalam air. (SNI 152094-2000):

\section{Bata Ringan}

Terdapat 2 jenis bata ringan yang sering digunakan pada dinding bangunan yaitu Autoclaved Aerated Concrete (ACC) dan Celluler Lightweigt Concrete (CLC). Kedua jenis bata ringan ini terbuat dari bahan dasar semen, pasir, dan kapur, yang berbeda adalah cara pembuatannya.

Salah satu bata ringan CLC adalah bata ringan Citicon dimana agregat kasar(kerikil) beton konvensional digantikan oleh udara yang dalam prosesnya menggunakan busa organik yang sangat stabil dan tidak ada reaksi kimia. Ketika proses pencampuran adonan, foam/busa berfungsi sebagai media untuk membungkus udara. Dengan kapasitas CLC yang rendah menyebabkan air tidak mudah merambat pada dinding bata ringan Citicon bila terjadi bocoran/rembesan air.(Kristanti,N., Transjaya A. pada Birdyant Goritman dkk 2012)

Salah satu produk bata ringan adalah bata ringan Citicon. Produk ini terbuat dari bahan dasar seperti kapur, silika dan semen. Citicon adalah bata ringan yang ramah lingkungan karena dibuat dengan bahan baku dan proses yang tidak merusak alam.

Bata ini cukup ringan, halus, dan memiliki tingkat kerataan yang baik sehingga bisa langsung diberi aci tanpa harus diplester terlebih dahulu.

\section{Pondasi dan Pile Cap}

Pondasi adalah bagian dari struktur bawah gedung yang kekuatannya ditentukan oleh kekuatan tanah yang mendukungnya, seperti fondasi telapak, rakit, tiang pancang dan tiang bor. (SNI - 1726 - 2002)

Pondasi ialah bagian bangunan yang menghubungkan gedung dengan tanah. Tanah harus menerima beban dari gedung (beban mati serta beban berguba) dan pondasi membagi beban itu, sehingga tekanan tanah yang diperbolehkan tidakdilewati. Pondasi harus diperhitungkan sedemikian rupa sehingga dapat menjamin kestabilan bangunan terhadap beban sendiri, beban berguna dan gaya-gaya luar seperti tekanan angin, gempa bumi dan lain-lain.

Pilecap merupakan suatu cara untuk mengikat pondasi sebelum didirikan kolom di bagian atasnya. Pile cap tersusun atas tulangan baja berdiameter $16 \mathrm{~mm}, 19 \mathrm{~mm}$ dan $25 \mathrm{~mm}$ yang membentuk suatu bidang dengan ketebalan dan lebar yang berbeda-beda tergantung dari jumlah tiang yang tertanam.

Fungsi dari pile cap adalah untuk menerima beban dari kolom yang kemudian akan terus disebarkan ke tiang pancang dimana masing-masing pile menerima $1 / \mathrm{N}$ dari beban oleh kolom dan harus $\leq$ daya dukung yang diijinkan ( $\mathrm{Y}$ ton) ( $\mathrm{N}=$ jumlah kelompok pile). Jadi beban maksimum yang bisa diterima oleh pile cap dari suatu kolom adalah sebesar $\mathrm{N} \times(\mathrm{Y}$ ton).

\section{Rencana Anggaran Biaya}

Rencana anggaran biaya merupakan perkiraan biaya yang diperlukan untuk setiap pekerjaan dalam suatu proyek konstruksi sehingga akan diperoleh biaya total yang diperlukan untuk menyelesaikan suatu proyek.tersebut.

\section{Analisis Software SAP 2000}

Program ini digunakan untuk analisis desain struktur menggunakan konsep metode elemen hingga yang didukung dengan analisis statis, dinamis, linier, maupun nonlinier.

Langkah - langkah analisis pada SAP 2000 seara garis besar sebagai berikut :

1. Menentukan geometri struktur

2. Menentukan material yang dipakai dan ukuran baloknya

3. Menentukan properti elemen

4. Menentukan beban mati dan beban hidup

5. Analisis model

\section{METODE PENELITIAN}

Metode penelitian yang digunakan adalah metode deskriptif dan komparatif. Metode deskriptif digunakan menganalisis dan mengolah data-data yang diperoleh dari lapangan maupun laboratorium secara faktual dan teliti.. Data-data tersebut diolah menggunakan aplikasi SAP 2000 untuk mengetahui hasil perhitungan beban-beban yang dipikul oleh pondasi. Sedangkan metode komparatif digunakan membandingkan hasil perhitungan harga rumah tipe 54 antara material penyusun dinding berupa bata merah dengan bata ringan.

Lokasi penelitian dilakukan pada Komplek Perdagangan Permai di Jalan Perdagangan, Kelurahan Alalak Utara, Kecamatan Banjarmasin Utara, Kota Banjarmasin.

Proses penelitian dapat dilihat pada diagram alir di gambar 2 .: 


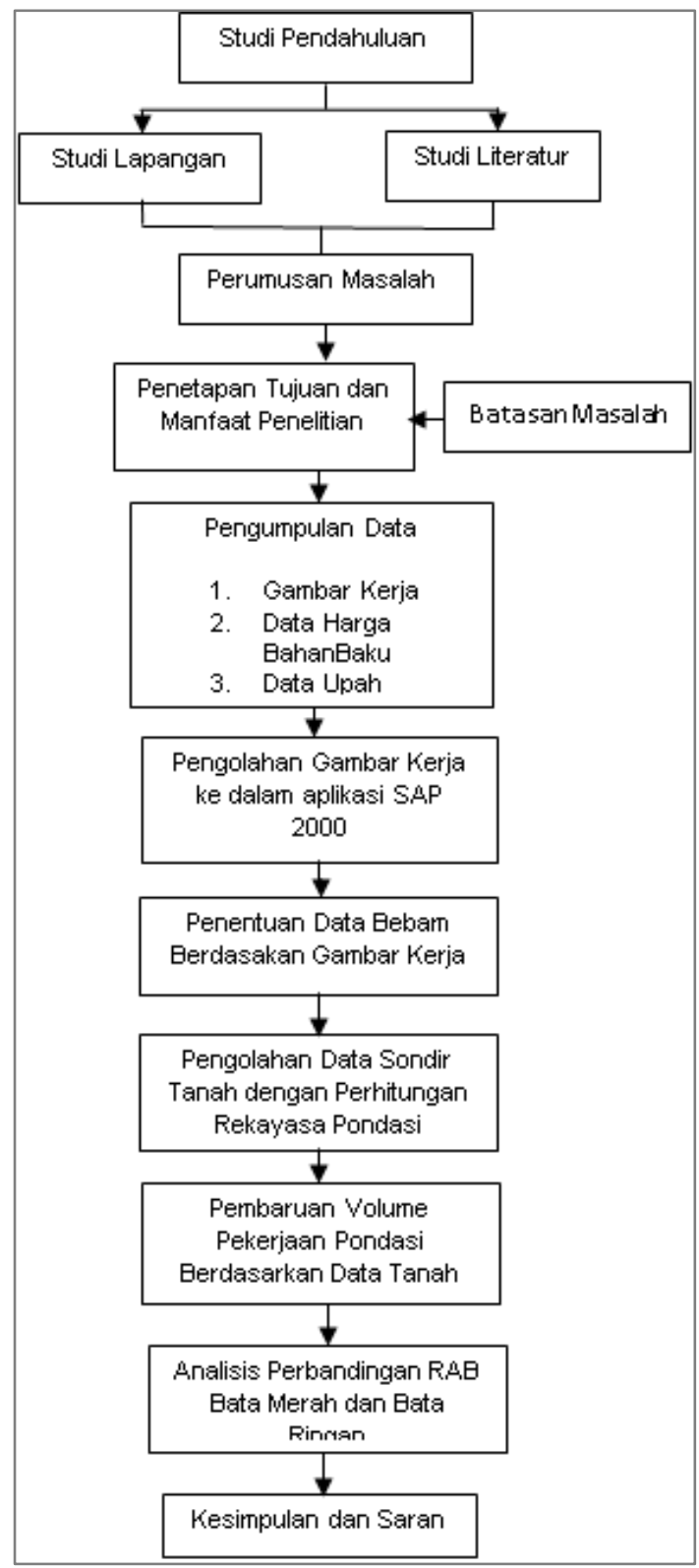

Gambar 1. Diagram Alir Penelitian

\section{HASIL DAN PEMBAHASAN}

\section{Data Material}

Spesifikasi teknik bata ringan Citicon :

1. Berat jenis kering : $530 \mathrm{~kg} / \mathrm{m} 3$

2. Berat jenis normal : $600 \mathrm{~kg} / \mathrm{m} 3$

3. Panjang $: 600 \mathrm{~mm}$

4. Tinggi $: 200 \mathrm{~mm}, 400 \mathrm{~mm}$

5. Tebal

: 75; 100; 125; 150; 175;

$200 \mathrm{~mm}$

6. Insulasi panas $: 0,14 \mathrm{~W} / \mathrm{mK}$

7. Kecepatan konstruksi : $>20 \mathrm{~m} 2 /$ hari

8. Daya serap air $: 4-6 \mathrm{~mm}$

9. Kuat Tekan : $>4 \mathrm{~N} / \mathrm{mm} 2$

10.Ketahanan terhadap api : 3 jam

(Sumber : www.Citicon.co.id -2014)
Spesifikasi teknik bata merah :

1. Berat jenis kering $\quad: 1.500 \mathrm{~kg} / \mathrm{m} 3$

2. Berat jenis normal $: 2.000 \mathrm{~kg} / \mathrm{m} 3$

3. Insulasi panas $: 0,65 \mathrm{~W} / \mathrm{mK}$

4. Kecepatan konstruksi $: 6-8 \mathrm{~m} 2 /$ hari

5. Kuat Tekan : $2,5-25 \mathrm{~N} / \mathrm{mm} 2$

6. Konduktifitas Termis (SII- 0021,1978 )

7. Tebal spesi $: 20-30 \mathrm{~mm}$

8. Ketahanan terhadap api : 2 jam

9. Jumlah(kebutuhan) per $1 \mathrm{~m}^{2}: 30-35$ buah (Sumber : www.Citicon.co.id- 2014, Dwina dkk 2014)

Perhitungan beban elemen struktur pada penelitian ini menggunakan analisis SAP 2000. Berdasarkan gambar kerja, kita masukkan beban-beban yang bekerja pada bangunan tersebut sesuai dengan fungsinya berdasarkan peraturan pembebanan. Untuk beban dinding pada balok pondasi, yaitu bata merah sebesar $250 \mathrm{~kg} / \mathrm{m}^{2}$ dan bata ringan sebesar $56 \mathrm{~kg} / \mathrm{m}^{2}$.

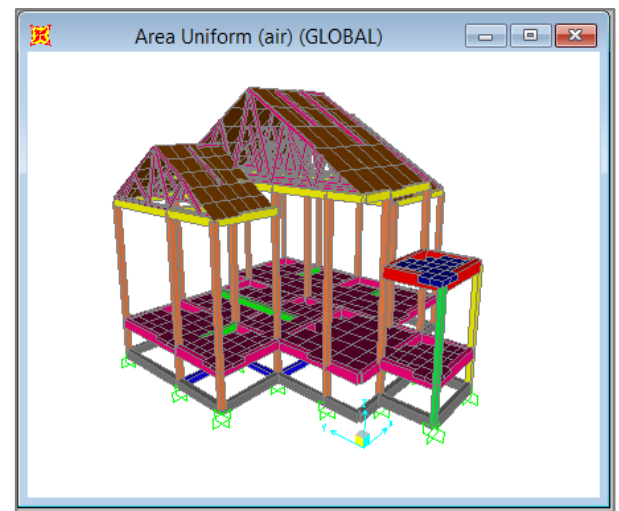

Gambar 2. Penggambaran Rumah pada SAP 2000

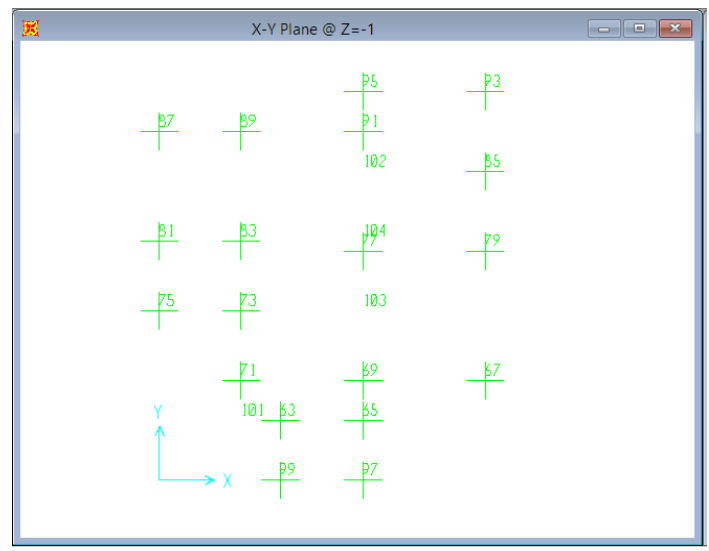

Gambar 3. Sketsa Joint Reaction

Semua beban dimasukkan, aplikasi SAP 2000 dirunning untuk mendapatkan data-data yang diperlukan. Pada penelitian ini data yang diperlukan adalah data dari Joint Reaction di F3. Kemudian dilakukan pengolahan data 
sondir tanah dengan perhitungan rekayasa pondasi untuk mengetahui perkuatan tanah, agar dapat mengoptimalkan jumlah tiang galam yang akan digunakan.

Perbedaan beban yang ditanggung pondasi, jumlah tiang galam yang diperlukan bata merah dan bata ringan dapat dilihat pada tabel 1.

Tabel 1. Perbandingan Beban yang Ditanggung Pondasi dan Jumlah Tiang Galam

\begin{tabular}{|c|c|c|c|c|}
\hline \multirow{2}{*}{$\begin{array}{c}\text { No } \\
\text { Joint }\end{array}$} & \multicolumn{2}{|c|}{$\begin{array}{c}\text { Beban yang } \\
\text { Ditanggung (Kgf) }\end{array}$} & \multicolumn{2}{c|}{$\begin{array}{c}\text { Jumlah Tiang } \\
\text { per Titik }\end{array}$} \\
\cline { 2 - 5 } & $\begin{array}{c}\text { Bata } \\
\text { Merah }\end{array}$ & $\begin{array}{c}\text { Bata } \\
\text { Ringan }\end{array}$ & $\begin{array}{c}\text { Ba ta } \\
\text { Merah }\end{array}$ & $\begin{array}{c}\text { Ba ta } \\
\text { Ringan }\end{array}$ \\
\hline 63 & 6336,01 & 4323,13 & 9 & 4 \\
\hline 65 & 3350,09 & 2203,61 & 12 & 6 \\
\hline 67 & 6209,95 & 3442,64 & 16 & 5 \\
\hline 69 & 11052,52 & 7182,82 & 12 & 6 \\
\hline 71 & 4186,91 & 2388,6 & 9 & 4 \\
\hline 73 & 8693,72 & 5916,52 & 16 & 5 \\
\hline 75 & 3350,47 & 1794,19 & 16 & 5 \\
\hline 77 & 16775,68 & 11935,1 & 16 & 5 \\
\hline 79 & 9649,72 & 5682,66 & 16 & 5 \\
\hline 81 & 7106,1 & 3926,43 & 9 & 4 \\
\hline 83 & 10103,06 & 7688,34 & 9 & 4 \\
\hline 85 & 5755,17 & 3490,09 & 9 & 4 \\
\hline 87 & 4553,82 & 2600,88 & 16 & 5 \\
\hline 89 & 8426,78 & 5619,53 & 9 & 4 \\
\hline 91 & 10179,62 & 6497,63 & 12 & 6 \\
\hline 93 & 4827,94 & 2649,34 & 16 & 5 \\
\hline 95 & 3229,33 & 1634,54 & 12 & 6 \\
\hline 97 & 2416,88 & 2005,63 & 9 & 4 \\
\hline 99 & 2211,87 & 1739,96 & 9 & 4 \\
\hline
\end{tabular}

Sumber: Hasil Perhitungan

Sedangkan perbedaan jumlah tiang galam, ukuran dimensi Pile Cap pada bata merah dan bata ringan dapat dilihat pada tabel 2.

Tabel 2. Perbandingan Jumlah Tiang Galam

Pondasi dan Ukuran Dimensi Pile Cap

\begin{tabular}{|c|c|c|c|c|}
\hline $\begin{array}{c}\text { No } \\
\text { Joint }\end{array}$ & \multicolumn{2}{|c|}{$\begin{array}{c}\text { Beban yang } \\
\text { Ditanggung } \\
\text { (Kgf) }\end{array}$} & \multicolumn{2}{|c|}{ Jumlah Tiang per Titik } \\
\cline { 2 - 5 } & $\begin{array}{c}\text { Bata } \\
\text { Mera } \\
\text { h }\end{array}$ & $\begin{array}{c}\text { Bata } \\
\text { Ringan }\end{array}$ & $\begin{array}{c}\text { Ba ta } \\
\text { Merah }\end{array}$ & $\begin{array}{c}\text { Ba ta } \\
\text { Ringan }\end{array}$ \\
\hline 63 & 9 & 4 & $75 \times 75$ & $55 \times 55$ \\
\hline 65 & 12 & 6 & $75 \times 100$ & $55 \times 85$ \\
\hline 67 & 16 & 5 & $100 \times 100$ & $55 \times 55$ \\
\hline 69 & 12 & 6 & $75 \times 100$ & $55 \times 85$ \\
\hline 71 & 9 & 4 & $75 \times 75$ & $55 \times 55$ \\
\hline 73 & 16 & 5 & $100 \times 100$ & $55 \times 55$ \\
\hline 75 & 16 & 5 & $100 \times 100$ & $55 \times 55$ \\
\hline 77 & 16 & 5 & $100 \times 100$ & $55 \times 55$ \\
\hline
\end{tabular}

\begin{tabular}{|c|c|c|c|c|}
\hline \multirow{2}{*}{$\begin{array}{c}\text { Noint } \\
\end{array}$} & \multicolumn{2}{|c|}{$\begin{array}{c}\text { Beban yang } \\
\text { Ditanggung } \\
\text { (Kgf) }\end{array}$} & \multicolumn{2}{|c|}{ Jumlah Tiang per Titik } \\
\cline { 2 - 5 } & $\begin{array}{c}\text { Bata } \\
\text { Mera } \\
\text { h }\end{array}$ & $\begin{array}{c}\text { Bata } \\
\text { Ringan }\end{array}$ & $\begin{array}{c}\text { Ba ta } \\
\text { Merah }\end{array}$ & $\begin{array}{c}\text { Ba ta } \\
\text { Ringan }\end{array}$ \\
\hline 79 & 16 & 5 & $100 \times 100$ & $55 \times 55$ \\
\hline 81 & 9 & 4 & $75 \times 75$ & $55 \times 55$ \\
\hline 83 & 9 & 4 & $75 \times 75$ & $55 \times 55$ \\
\hline 85 & 9 & 4 & $75 \times 75$ & $55 \times 55$ \\
\hline 87 & 16 & 5 & $100 \times 100$ & $55 \times 55$ \\
\hline 89 & 9 & 4 & $75 \times 75$ & $55 \times 55$ \\
\hline 91 & 12 & 6 & $75 \times 100$ & $55 \times 55$ \\
\hline 93 & 16 & 5 & $100 \times 100$ & $55 \times 55$ \\
\hline 95 & 12 & 6 & $75 \times 100$ & $55 \times 85$ \\
\hline 97 & 9 & 4 & $75 \times 75$ & $55 \times 55$ \\
\hline 99 & 9 & 4 & $75 \times 75$ & $55 \times 55$ \\
\hline
\end{tabular}

Sumber: Hasil Perhitungan

Berkurangnya jumlah galam pada titik joint dapat mempengaruhi dimensi pile cap, karena semakin banyak tiang yang digunakan maka semakin besar pula dimensi pile cap-nya. Pada saat pemakaian material penyusun dinding bata merah dimensi pile cap beserta jumlah galam yang diperlukan sesuai dengan gambar kerja yang sudah ada. Pada saat pemakaian material penyusun dinding bata ringan dimensi pilecap mengalami perubahan sesuai dengan perhitungan jumlah titik galam

Terdapat perbedaan volume pekerjaan berdasarkan material penyusun dinding bata merah dan bata ringan. Pada pemakaian materi penyusun dinding dari bata merah, jumlah galam yang diperlukan sebanyak 1624 m' dan volume cor beton untuk pondasi sebanyak 4,51 $\mathrm{m}^{3}$. Pada Pemakaian materi penyusun dinding dari bata ringan, jumlah galam yang diperlukan sebanyak $631 \mathrm{~m}$ ' dan volume cor beton untuk pondasi sebanyak 2,0085 $\mathrm{m}^{3}$. Perbedaan volume pekerjaan dapat mempengaruhi biaya pekerjaan tersebut.

Perbedaan bentuk, ukuran dan jumlah galam pada pile cap $P_{1}, P_{2}$ dan $P_{3}$. yang digunakan pada pembangunan rumah tipe 54 dapat dilihat pada tabel 3 .

Tabel 3. Perbedaan Bentuk, Ukuran dan Jumlah Galam pada Pile Cap

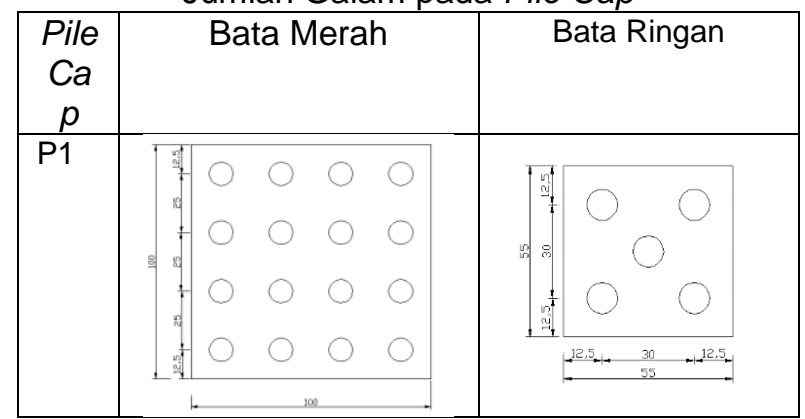




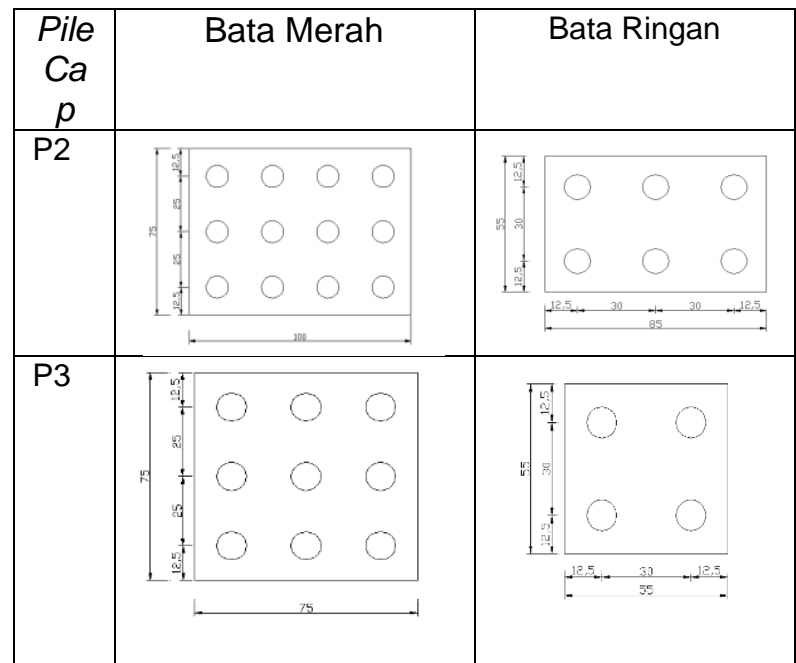

Sumber: Gambar Kerja dan Hasil Perhitungan

Perbedaan rencana anggaran biaya rumah tipe 54 berdasarkan material penyusun dinding yang dipakai yaitu bata merah dan bata ringan dapat dilihat pada tabel 4 .

Tabel 4. Rencana Anggaran Biaya Rumah Tipe 54 Menggunakan Bata Merah dan Bata Ringan

\begin{tabular}{|c|c|c|c|}
\hline No & $\begin{array}{l}\text { Uraian } \\
\text { Pekerjaan }\end{array}$ & $\begin{array}{l}\text { Bata } \\
\text { Merah(Rp) }\end{array}$ & $\begin{array}{l}\text { Bata } \\
\text { Ringan(Rp) }\end{array}$ \\
\hline A & $\begin{array}{l}\text { Pekerjaan } \\
\text { Persiapan }\end{array}$ & $6.176 .043,38$ & $6.176 .043,38$ \\
\hline B & $\begin{array}{l}\text { Pekerjaan } \\
\text { Tanah }\end{array}$ & $80.718 .899,63$ & $33.656 .321,48$ \\
\hline $\mathrm{C}$ & Pekerjaan Beton & $108.027 .378,41$ & $100.052 .754,46$ \\
\hline D & $\begin{array}{l}\text { Pekerjaan } \\
\text { Lantai }\end{array}$ & $17.095 .403,45$ & $17.095 .403,45$ \\
\hline$E$ & $\begin{array}{l}\text { Pekerjaan } \\
\text { Dinding }\end{array}$ & $44.835 .514,22$ & $53.259 .180,28$ \\
\hline $\mathrm{F}$ & Pekerjaan Atap & $46.898 .908,94$ & $46.898 .908,94$ \\
\hline $\mathrm{G}$ & $\begin{array}{l}\text { Pekerjaan } \\
\text { Pengecatan }\end{array}$ & $4.350 .400,74$ & $4.350 .400,74$ \\
\hline $\mathrm{H}$ & $\begin{array}{l}\text { Pekerjaan } \\
\text { Kusen, Pintu } \\
\text { Dan Jendela }\end{array}$ & $22.872 .857,72$ & $22.872 .857,72$ \\
\hline 1 & $\begin{array}{l}\text { Pekerjaan } \\
\text { Kuncian }\end{array}$ & $3.641 .548,60$ & $3.641 .548,60$ \\
\hline $\mathrm{J}$ & Pekerjaan Listrik & $3.360 .709,40$ & $3.360 .709,40$ \\
\hline $\mathrm{K}$ & $\begin{array}{l}\text { Pekerjaan } \\
\text { Sanitasi }\end{array}$ & $12.986 .610,70$ & $12.986 .610,70$ \\
\hline \multicolumn{2}{|r|}{ Total } & $350.964 .275,17$ & $304.350 .739,13$ \\
\hline
\end{tabular}

Perbandingkan harga per-pekerjaan antara penggunaan bata merah dan bata ringan dapat dilihat pada tabel 5 .

Tabel 5. Perbandingan Biaya Pekerjaan

\begin{tabular}{|c|c|c|c|}
\hline \multirow{2}{*}{$\begin{array}{l}N \\
0\end{array}$} & \multirow{2}{*}{$\begin{array}{c}\text { Uraian } \\
\text { Pekerjaan }\end{array}$} & \multicolumn{2}{|c|}{ Jumlah Harga Per-Pekerjaan } \\
\hline & & Bata Merah & Bata Ringan \\
\hline 1 & $\begin{array}{l}\text { Pemancangan } 1 \\
\text { m' galam }\end{array}$ & $77.436 .298,80$ & $30.373 .720,65$ \\
\hline 2 & $\begin{array}{l}\text { Pekerjaan } 1 \mathrm{~m}^{3} \\
\text { Pondasi Beton } \\
\text { Bertulang }\end{array}$ & $14.377 .595,04$ & $6.402 .971,09$ \\
\hline 3 & $\begin{array}{l}\text { Pasangan } 1 / 2 \\
\text { batu bata camp. }\end{array}$ & 15.003.269,14 & 24.693.399,84 \\
\hline
\end{tabular}

\begin{tabular}{|c|l|c|c|}
\hline $\mathbf{N}$ & \multicolumn{1}{|c|}{ Uraian } & \multicolumn{2}{|c|}{ Jumlah Harga Per-Pekerjaan } \\
\hline & $1: 3$ & & $18.894 .354,04$ \\
\hline 4 & $\begin{array}{l}\text { Plesteran } \\
\text { dinding tebal 15 } \\
\text { mm camp. 1:3 }\end{array}$ & $18.894 .354,04$ & $\begin{array}{l}\text { 10.937.891,04 } \\
\text { Pemasangan 1 } \\
\text { m2 acian }\end{array}$ \\
\hline \multicolumn{2}{|c|}{ TOTAL } & $136.649 .407,03$ & $90.035 .872,02$ \\
\hline
\end{tabular}

Sumber : Hasil Perhitungan

Harga material untuk pemasangan dinding menggunakan bata ringan lebih mahal 1,64 kali dibandingkan menggunakan bata merah. Namun volume pekerjaan pondasi dapat diminimumkan berdasarkan beban yang ditanggung dari dinding karena bata ringan lebih ringan dibandingkan dengan bata merah Berubahnya dimensi pile cap mempengaruhi volume pekerjaan pondasi, sehingga harga yang didapat juga mengalami perubahan. Harga untuk pekerjaan pondasi dengan material penyusun dinding berupa bata ringan 2,4 kali lebih murah dibanding menggunakan bata merah.

\section{E. PENUTUP \\ Kesimpulan}

1. Penggunaan bata merah dan bata ringan mempengaruhi dimensi pondasi. Dimensi pile cap $\mathrm{P}_{1}$ pada penggunaan material bata merah adalah $100 \mathrm{~cm} \times 100 \mathrm{~cm}$, pada penggunaan material bata ringan adalah 55 $\mathrm{cm} \times 55 \mathrm{~cm}$. Dimensi pile cap $\mathrm{P}_{2}$ pada penggunaan material bata merah adalah 100 $\mathrm{cm} \times 75 \mathrm{~cm}$, pada penggunaan material bata ringan adalah $55 \times 85 \mathrm{~cm}$. Dimensi pile cap $\mathrm{P}_{3}$ pada penggunaan material bata merah adalah $75 \mathrm{~cm} \times 75 \mathrm{~cm}$, pada penggunaan material bata ringan adalah 55 $\mathrm{cm} \times 55 \mathrm{~cm}$.

2. Penggunaan bata merah dan bata ringan mempengaruhi harga bangunan rumah tipe 54. Pada penggunaan bata merah harga rumah adalah $\mathrm{Rp} 350.964 .275$ (tiga ratus lima puluh juta sembilan ratus enam puluh empat ribu dua ratus tujuh puluh lima rupiah) sedangkan pada penggunaan bata ringan harga rumah adalah $\mathrm{Rp} 304.350 .739$ (tiga ratus empat juta tiga ratus lima puluh ribu tujuh ratus tiga puluh sembilan rupiah).

\section{Saran}

1. Bata ringan disarankan digunakan sebagai material penyusun dinding bangunan pada lahan rawa atau tanah lunak.

2. Perlu penelitian lebih lanjut tentang analisis pengaruh penggunaan material bata merah dan bata ringan terhadap struktur bagian atas. 


\section{F. DAFTAR PUSTAKA}

1. Dwina Oni Susanto dkk, (2014), Perbandingan Penggunaan Material Batu Bata Merah dengan Bata Ringan I-CON akibat Perubahan Desain Struktur ditinjau dari Biaya dan Waktu, Jurnal Pomits Vol 3. No. 2,(2014) ISSN : 2337-3539(2301-9271 Print).

2. Goritman, Birdyant, Robby Irwangsa, Jonathan Hendra Kusuma (2012). Studi Kasus Perbandingan Berbagai Bata Ringan Dari Segi Material, Biaya, Dan Produktivitas. Surabaya: Jurnal Teknik Sipil. Vol 1, No 1.

3. Putra, H.P. (2010), Studi Perbandingan Biaya Pelaksanaan Pekerjaan Dinding Menggunakan Bata Ringan. http:/ml.sribd.com/doc/33631003/hargasatuan-pekerjaan.

4. Siregar, N. (2010). Tanah Liat Pada Pembuatan Batu Bata. Medan: Skripsi Universitas Sumatera Utara.

5. Suwardono. (2002). Mengenal Pembuatan Bata, Genteng Berglasir. Bandung: Yrama Widya.

6. URL: http//www.Citicon.co.id (2014). 